УДК 338.48

DOI: https://doi.org/10.37320/2415-3583/14.12

Постова В.В.

кандидат економічних наук, старший викладач кафедри туризму та готельно-ресторанної справи, Вінницький торговельно-економічний інститут Київського національного торговельно-економічного університету ORCID: https://orcid.org/0000-0002-0056-5648

Лук'янець А.В. старший викладач кафедри туризму та готельно-ресторанної справи, Вінницький торговельно-економічний інститут Київського національного торговельно-економічного університету ORCID: https://orcid.org/0000-0002-9973-5386

\title{
ОСОБЛИВОСТІ ФОРМУВАННЯ ТА ПІДТРИМКА ІМІДЖУ ПІДПРИЕМСТВ ГОТЕЛЬНО-РЕСТОРАННОГО БІЗНЕСУ
}

\begin{abstract}
У статті розглянуто специифіку надання послуг розмішення у закладах готельного господарства. Визначено фактори, щзо впливають на формування сприятливого іміджу підприємств сфери обслуговування, які поділено на 4 групи. Встановлено, щчо споживача послуг, як правило, цікавлять відповідність иіни і якості послуг, щео надаються. У комплексі функиій менеджменту на підприємствах сфери послуг одне з провідних місиь посідає управління процесом обслуговування клієнтів. Головною особливістю формування іміджу готельно-ресторанного підприємства є залежність сприйняття иьього закладу від туристської дестинації, на якій вона розташовується. Визначено, щзо такий підхід полягає у присвоєнні кожному готельному чи ресторанному підприємству іміджу всього курорту, оскільки у туриста, найімавірніше, вже є сформоване уявлення про дестинації.
\end{abstract}

Ключові слова: готельно-ресторанний бізнес, сфера послуг, імідж, обслуговування, послуги, Public Relations.

Постановка проблеми. У процесі ринкової трансформації економіки суспільство переживає системні перетворення у всіх сферах життєдіяльності: політичній, правовій, економічній, соціальній. Розвиток ринкової економіки привів до збільшення такого складного і різноманітного спрямування діяльності в сфері послуг, як послуги готельно-ресторанного бізнесу. Як жодна інша галузь, цей напрям діяльності вимагає серйозного осмислення світового досвіду та пильної уваги до перспектив його використання в Україні. 3 цих позицій важливим $є$ визначення ролі і значення цього виду бізнесу в сучасній економіці, визначення динаміки його розвитку в нашій країні і за кордоном, порівняння тенденцій становлення цього бізнесу в різних країнах 3 метою внесення корисного в українську специфіку.

Готельно-ресторанний бізнес - це один із видів економічної діяльності, який відносять до малого і середнього бізнесу, що прямо або побічно створює робочі місця і $є$ важливим засобом поповнення скарбниці іноземною валютою. У світі постійно відбувається процес осмислення нових концепцій розвитку готельно-ресторанного, його модернізація.

Нині однією зі складових частин успіху підприємства стає позитивний імідж, що сприяє зростанню конкурентоспроможності та ефективності діяльності. Імідж виступає важливим засобом для досягнення намічених підприємством стратегічних цілей. У зв'язку 3 цим зростає значення розроблення конкретних заходів щодо формування позитивного іміджу та зниження рівня ризику втрати репутації підприємства.

Аналіз останніх досліджень і публікацій. Однак у сучасній навчальній літературі та періодичних виданнях недостатньо розкриті особливості формування іміджу підприємства, що впливає на ризик втрати репутації. Одним із головних чинників конкурентної боротьби на ринку сфери послуг виступає імідж підприємства. Особливе значення цей чинник набуває під час формування переваг клієнтів, оскільки успіх взаємин залежить насамперед від ступеня довіри клієнта.

У становлення і розвиток ринкової теорії і практики вітчизняної економіки гостинності великий внесок зробили І. Альошина, К. Антипов, В. Баринов, Р. Горчакова, Т. Кисліцина, С. Лозівський, О. Завадинська [1], В. Завальнюк [2], Д. Зленко, С. Самойлова, Л. Фомченкова, Е. Пекишева [3], Е. Пилипівський, В. Русавська [4], А. Чернишов та інші. Їхні маркетингові дослідження присвячені соціально-економічним проблемам розвитку сфери обслуговування, основним принципам функціонування сфери послуг, взаємозв’ язку туризму 3 іншими галузями економіки.

Водночас проблеми формування іміджу в готельноресторанному бізнесі, особливо на регіональному рівні, не отримали належного висвітлення у працях вітчизняних дослідників, в економічній науці досі не склався чіткий і несуперечливий категорійно-понятійний апарат.

Недостатня розробленість проблем готельно-ресторанного бізнесу і необхідність їх узагальнення та вирішення визначили актуальність цього дослідження.

Мета дослідження полягає в розробленні методологічних основ формування іміджу організації в діяльності підприємств готельно-ресторанного бізнесу.

Виклад основного матеріалу. Формування іміджу підприємств сфери обслуговування є нелегким методом підвищення конкурентоспроможності підприємства. У готельно-ресторанному господарстві України 3'явилися дорогі готелі високого класу (4-5 зірок) та ресторани. Це, як правило, заклади, де співзасновниками є зарубіжні компанії, які пропонують сучасні технології обслуговування споживачів відповідно до 
міжнародних стандартів і правил. За останні роки різко збільшився виїзний туризм, з'явилася можливість порівняти рівень обслуговування в зарубіжних готельно-ресторанних підприємствах із тим, що надають вітчизняні заклади. Це порівняння виявилося не на користь українських підприємств.

Всі ці фактори вплинули на зниження завантаження номерного фонду наявних готельних підприємств та зменшення кількості відвідувачів вишуканих закладів ресторанного господарства. Якщо раніше готелі та ресторани були в основному бюджетними організаціями, то зараз це сфера приватного капіталу, отже, від завантаження цих закладів прямо залежить їхній дохід. Підвищення напруженості в конкурентній боротьбі за кожного клієнта веде до змін у відносинах з працівниками, тому заклади готельно-ресторанного господарства підвищують вимоги до персоналу. Таким чином, зросла конкуренція в боротьбі не лише за клієнта, а й за робочі місця. У реальних умовах врахувати всіх конкурентів окремо взятого готельно-ресторанного підприємства досить складно, оскільки на ринку цих послуг представлено значну кількість конкуруючих підприємств, дослідити кожне 3 яких не видається можливим.

На імідж підприємства готельно-ресторанної індустрії впливає безліч факторів, що визначають силу бізнесу, здатність підприємства функціонувати в поточних економічних і політичних умовах, тобто вирішувати податкові проблеми; забезпечувати фінансову стійкість і незалежність, займатися оснащенням матеріально-технічної бази підприємства і знижувати ступінь іï зносу, організацією діяльності всіх напрямів - фінансової, господарської, збутової, аналітичної, яка обслуговує тощо. Але ці чинники визначають тільки одну сторону іміджу закладів готельно-ресторанного господарства - 3 позиції власника. Споживач, орієнтуючись на привабливість послуги, сприяє підвищенню конкурентоспроможності цих закладів, забезпечуючи їм дохід і можливість реалізації вищевказаних чинників, а також підвищуючи зовнішній імідж готелю чи ресторану.

Вибір, обгрунтування, групування і ранжування ступеня впливу чинників на імідж готельно-ресторанного підприємства слід здійснювати 3 урахуванням специфіки його діяльності. Ринок послуг має низку специфічних рис, таких як: висока динамічність ринкових процесів; територіальна сегментація; локальний характер послуг; короткий цикл обігу послуги; високу чутливість до змін ринкової кон'юнктури; особистий контакт споживача і виробника послуги; індивідуальність попиту; неможливість попередньої оцінки якості послуги.

Послуги розміщення мають додаткову специфіку:

1. Різний клас послуг, що надаються.

2. Безпосереднє споживання послуг у процесі ї надання.

3. Залежність результатів господарської діяльності готельно-ресторанного підприємства від коливань попиту на послуги.

4. Низька еластичність пропозиції.

5. Висока фондомісткість.

6. Безперервність надання готельних послуг (готель працює 24 години на добу, 365 днів на рік).

7. Індивідуальний характер надання послуг, який заснований на особливих вимогах клієнтів [1].
3 огляду на все вищесказане, фактори, що впливають на формування сприятливого іміджу підприємств сфери обслуговування, доцільно розділити на 4 групи [2]:

- фактори, що характеризують підприємство;

- фактори, що характеризують послугу; єнтів;

- фактори, що характеризують обслуговування клі-

- фактори, що характеризують маркетинг.

Значущість і характер впливу цих груп чинників на забезпечення позитивного іміджу підприємства сфери обслуговування різна.

Так, фактори I-ї групи покликані показати характеристики самого підприємства.

Фактори II-ї групи відображають параметри послуги розміщення. До факторів іміджу послуг готельно-ресторанного підприємства відносяться: ціна послуги; клас послуг; структура і стан номерного фонду; кількість торговельних приміщень закладів ресторанного господарства; якість інженерно-технічного забезпечення послуги; якість господарського забезпечення послуги; безпека послуги.

Споживача послуг, як правило, цікавлять відповідність ціни і якості послуг, що надаються. В останні роки спостерігається пріоритет якісних параметрів послуги. I все ж конкурентоспроможність підприємств сфери обслуговування багато в чому залежить від еффектівності цінової політики, яка проводиться закладами готельно-ресторанного господарства. Використання цього інструменту в готельно-ресторанному бізнесі пов'язане $з$ певним ризиком, оскільки за невмілого поводження 3 ним можуть бути отримані непередбачувані і навіть негативні за своїми економічними наслідками результати [3].

Надання послуг сфери обслуговування пов'язане 3 обов'язковим використанням певного обладнання та інвентарю, тому якість інженерно-технічного забезпечення послуги також названо у складі факторів, що характеризують послугу. Забезпеченням справності роботи інженерно-технічного обладнання готельно-ресторанного підприємства займається служба технічної експлуатації (інженерно-технічна служба). Вона проводить обслуговування та ремонт санітарно-технічного обладнання (водопровід, каналізація, гаряче водопостачання, вентиляція, кондиціонування повітря, сміттєпровід); енергетичного господарства; слабкострумових пристроїв і засобів автоматики; систем телебачення і зв'язку; холодильного обладнання; комп'ютерної техніки та ін.

Одним із факторів, що забезпечують відповідний рівень проживання в готелі, є забезпечення безпеки послуги, тобто безпеки перебування самого гостя в готелі і безпеки та збереження його майна, що і стосується безпечності перебування у закладі ресторанного господарства. Ці параметри певною мірою впливають і на формування репутації готельного чи ресторанного підприємства, оскільки відчуття безпеки - це та характеристика послуги, яка цікавить багатьох користувачів послугами сфери обслуговування.

Фактори III-ї групи є вельми специфічними і характеризують рівень і якість обслуговування клієнтів. Ці параметри формування іміджу знаходяться «на поверхні». На відміну від фінансового стану підприємства, кадровий потенціал та рівень обслуговування досить просто і чітко може оцінити клієнт. 
Варто також відзначити, що до складу третьої групи факторів входить дотримання стандартів обслуговування. $€$ кілька рівнів стандартів обслуговування: міжнародні стандарти; стандарти вітчизняних асоціацій; державні (національні) стандарти; внутрішні стандарти підприємства.

Четверта група факторів характеризує маркетинг. Його дуже часто розглядають як філософію бізнесу і конкретне керівництво до дії. 3 одного боку, вміло організована маркетингова діяльність дає уявлення про те, які можливості він надає для успішної роботи в умовах конкурентного ринку.

Отже, в комплексі функцій менеджменту на підприємствах сфери послуг одне 3 провідних місць посідає управління процесом обслуговування клієнтів. Реалізації цієї функції повинна приділятися велика увага в силу іiі високої значущості у забезпеченні розвитку підприємства сфери послуг і підвищенні ефективності його діяльності.

На розвиток готельно-ресторанного бізнесу великий вплив робить такий фактор, як імідж закладу, що забезпечує сприятливе сприйняття готелю чи ресторану, які відомі споживачам. Імідж готелю чи ресторану загалом складається з місця розміщення закладу, ціни номерів, цін із меню, пропонованих послуг зручностей, зовнішнього сприйняття і внутрішньої атмосфери, рівня кваліфікації обслуговуючого персоналу тощо.

Головною особливістю формування іміджу готельно-ресторанного підприємства $є$ залежність сприйняття цього закладу від туристської дестинації, на якій він розташовується. Такий підхід полягає у присвоєнні кожному готельному чи ресторанному підприємству іміджу всього курорту, оскільки у туриста, нацйімовірніше, вже є сформоване уявлення про дестинації, яке базується не тільки на туристській привабливості регіону, а й на зовсім сторонніх аспектах, таких як, наприклад, особливості менталітету населення, рівень економічного розвитку або політична обстановка, які так чи інакше здатні впливати на ключові характеристики вибору готелю чи ресторану клієнтом.

Наступна значуща особливість полягає у відмінності пріоритетів різних сегментів споживачів. Діловий клієнт насамперед звертатиме увагу на наявність трансферу, конференц-зали та дитячої кімнати; іншому ж типу споживача, такому як, наприклад, клієнтові-одинаку без дітей, який прибув із пізнавальними цілями, дитяча кімната й інші перераховані вище особливості будуть абсолютно байдужі, і ключовим моментом вибору може бути наявність екскурсійного обслуговування, місце розташування готелю (біля моря, гір чи пам'ятників культури або релігії) i наявність різних розважальних програм у закладі ресторанного господарства.

До інших особливостей формування іміджу готельного чи ресторанного підприємства слід віднести візуальну складову частину іміджу (зовнішній вигляд будівель, персоналу), рівень інноваційності та якості послуг, що надаються, i, нарешті, співпрацю 3 іншими закладами та мережами (в тому числі закордонними).

Однак специфічність іміджу практично будь-якого підприємства туристської сфери насамперед визнача- ється властивостями послуг, що надаються. У маркетинговій сфері виділяють п'ять таких особливостей туристської послуги: невідчутність; неможливість відділення джерела від об'єкта; динамічність якості; неможливість зберігання [4].

Отже, послідовно розкриємо зміст кожної з особливостей на прикладі готельно-ресторанного комплексу:

1. Невідчутність. Отримати конкретну інформацію про споживання послуги, яка одержана на основі власного досвіду, неможливо до моменту безпосереднього iii вживання, iii не можна спробувати на смак, іiі неможливо побачити, почути або помацати, чого не можна сказати про будь-який матеріальний товар.

2. Невіддільність від джерела й об'єкта. Як уже було згадано вище, власник готелю не може взяти з собою номер на виставку, щоб представити його публіці саме там. Звідси випливає, що невід'ємними атрибутами надання послуги є присутність тих, хто її надає, того, хто іiі отримує, безпосередньо і виключно на місці надання самої послуги. Що стосується ще одного аспекту цієї особливості, то він полягає в тому, що обидві сторони укладання угоди повинні знати умови, за яких можна здійснити надання турпослуги.

3. Динамічність якості. Характерна особливість номенклатури послуг сфери готельно-ресторанного бізнесу полягає в іiї високій варіативності, оскільки якість їх надання залежить від безлічі факторів: як, хто, коли і в яких умовах іiї надає. Це пояснюється нерозривністю надання та споживання, що помітно обмежує здатність здійснювати контроль якості в цей час. До слова, скачки попиту в певні періоди (сезонність) також обмежують цей процес.

4. Неможливість зберігання. Через свій характер нематеріальності послуги їх зберігання стає неможливим. Крім таких факторів, як місце розташування готелю, ціна номерів, пропоновані послуги та зручності, формування корпоративного іміджу готельного чи ресторанного підприємства також має свої особливості, які сформувалися завдяки послугам, характерним для галузі готельно-ресторанного господарства - особливості туристичного продукту (невідчутність, невіддільність джерела від об'єкта, динамічність якості і неможливість зберігання).

Public Relations $є$ сьогодні галуззю, яка активно розвивається i, як і реклама, стоїть на перехресті науки i мистецтва. Як приклади, наводимо такий перелік PR-акцій, що застосовуються в практиці підприємств готельно-ресторанного господарства i впливають як на залучення нових споживачів послуг і на створення постійної клієнтури, так і на просування товару на ринку загалом:

1. Проведення прес-конференцій.

2. Статті в ЗМІ (спеціалізованих і громадських). Розміщення спеціальних статей в ЗМІ туристичної спрямованості і 3МI, що публікують світську хроніку. Такий крок призначений для вузького кола потенційних партнерів у сфері туристичної індустрії. Поява статей у громадських виданнях організовується з метою залучення такої категорії клієнтури, як приватний клієнт і клієнт ділового середовища.

3. Участь в соціально значущих акціях. Така діяльність дає змогу підвищити значущість готелю чи ресторану як серед потенційних споживачів, так і у влад- 
них структурах і громадських організаціях, що, в свою чергу, дає змогу посилити PR-діяльність із використанням позитивних відносин із державними органами.

4. Електронне представництво підприємства готельно-ресторанного господарства. Останнім часом відсутність у закладу власного сайту викликає, м'яко кажучи, подив як у турфірми, так і у потенційних гостей. Сайт - це єдиний досить дешевий для будь-якого закладу спосіб доносити інформацію про готель чи заклад ресторанного господарства в будь-яку точку світу 3 можливістю змінювати цю інформацію в реальному часі, тому створення сайтів - це велика потреба будьякого закладу. Електронне представництво закладу готельно-ресторанного господарства включає: розроблення сайту в Інтернеті, розроблення концепції «віртуального» підприємства для демонстраційних презентацій, уявлення про заклад на туристичних порталах, участь у глобальних системах бронювання.

5. Формування повного спектру поліграфічної продукції, яка говорить про концепцію закладу готельноресторанного господарства.

6. Корпоративний внутрішній PR.

7. Проведення урочистостей, таких як національні свята, організація в закладі виставок по мистецтву, проведення тематичних карнавалів; різного типу благодійні заходи; тижні кухонь різних регіонів; дегустація вин для знавців.

8. Складання інформаційного поля за потребами клієнта: архів даних по місцях відпочинку, дозвілля (ресторани, фітнес-зали, сауни), інформація про місцеві культурні та історичні пам'ятки.

9. Продаж товару з символікою закладу готельноресторанного господарства [5].

PR сприймається найчастіше як діалог, в якому інформація не тільки йде до клієнта, а й виходить від нього. На цьому і побудований контроль ефективності та діяльності таких заходів: $з$ одного боку, простежують правильність проведення PR-дій і заходів, охоплення ними певних цільових груп на підприємствах готельно-ресторанного бізнесу, а з іншого - організують облік взаємних інтересів партнерів.

Імідж закладу готельно-ресторанного господарства не повинен втрачати своєї актуальності і в кінцевому підсумку перестане бути іміджем як таким. Якщо заклад готельно-ресторанного господарства не хоче втрачати свої позиції на ринку, то його рейтинг повинен постійно підтримуватися, а стиль - оновлюватися, хоча б навіть у введенні незначних елементів новизни, що дають змогу закладу завжди залишатися «свіжим», оригінальним і незабутнім.

Висновки. Підводячи підсумок цього дослідження, можна зробити висновок, що імідж організації є деякою мірою мистецтвом переконувати людей і впливати на їхню думку, підтримувати готовність до необхідних змін, запобігати і усувати кризові ситуації, формувати і підтримувати позитивну репутацію, що неможливо без використання спеціальних PR-технологій. PR-технології у сфері готельно-ресторанного бізнесу являють собою сукупність послідовно застосовуваних процедур, прийомів і способів діяльності 3 організації для створення іміджу, спрямованих на найбільш оптимальну й ефективну реалізацію цілей і завдань суб'єкта управління в певний час і в певному місці. Завдання складання іміджу організації полягає в тому, щоб налагодити взаєморозуміння, позитивне ставлення і довіру клієнта до пропозиції і послуг підприємства, в нашому разі - закладів готельноресторанного господарства, на тривалу перспективу. Йдеться про формування в очах громадськості позитивного іміджу, хорошої репутації і поваги до підприємства. Позитивний імідж як одна з PR-технологій $€$ визначальною складовою частиною успіху діяльності закладів готельно-ресторанного бізнесу.

Перспективами подальших досліджень можуть стати розроблення ефективної стратегії формування позитивного іміджу для закладів готельно-ресторанного бізнесу, а також розроблення механізму визначення ефекту від розробленого іміджу.

\section{Список використаних джерел:}

1. Завадинська О.Ю. Інноваційні маркетингові методики підвищення лояльності споживачів послуг сфери ресторанного бізнесу. Вісник Київського наџіонального університету культури і мистеитв. Серія: Менеджмент соиіокультурної діяльності. 2018. С.137-148.

2. Завальнюк В.В. Розробка методики проектування маркетингової підсистеми в системі стратегічного управління інноваціями. Причорноморські економічні студї. № 7. 2016. С.112-116.

3. Пекишева Е.П. Инновационный механизм управления ресторанным бизнесом: автореферат дисс. кандидата экономических наук 08.00.05М. : Ин-т междунар. права экономики им. А.С. Грибоедова, 2012. 26 с.

4. Русавська В.А., Костюченко І.А. Послуга як нематеріальна складова сервісної діяльності. Друкується за рішенням Вченої ради Київського національного університету культури і мистецтв (протокол № 27 від 3 жовтня 2018 р.). 261с.

5. Швець В.В., Мазуркевич І.О., Лук'янець А.В. Архітектура як чинник формування іміджу готельного підприємства. Сучасні технології, матеріали і конструкиії в будівництві. 2018. № 2. С. 102-106.

\section{References:}

1. Zavadynsjka O.Ju. (2018) Innovacijni marketynghovi metodyky pidvyshhennja lojaljnosti spozhyvachiv poslugh sfery restorannogho biznesu [Innovative marketing methods to increase the loyalty of consumers of restaurant services]. Visnyk Kyjivsjkogho nacionaljnogho universytetu kuljtury i mystectv. Serija: Menedzhment sociokuljturnoji dijaljnosti. Pp. 137-148.

2. Zavaljnjuk V.V. (2016) Rozrobka metodyky proektuvannja marketynghovoji pidsystemy v systemi strateghichnogho upravlinnja innovacijamy [Development of methods for designing a marketing subsystem in the system of strategic innovation management]. Prychornomorsjki ekonomichni studiji, no. 7, pp. 112-116.

3. Pekisheva E.P. (2012) Innovatsionnyy mekhanizm upravleniya restorannym biznesom [An innovative mechanism for managing the restaurant business]: (PhD Thesis). In-t mezhdunar. prava ekonomiki im. A.S. Griboedova.

4. Rusavsjka V.A., Kostjuchenko I.A. (2018) Poslugha jak nematerialjna skladova servisnoji dijaljnosti [Service as an intangible component of service activities]. Drukujetjsja za rishennjam Vchenoji rady Kyjivsjkogho nacionaljnogho universytetu kuljtury i mystectv (protokol 27 vid 3 zhovtnja 2018). 
5. Shvets V. V., Mazurkevych I.O., Lukianets A.V. (2018) Arkhitektura yak chynnyk formuvannia imidzhu hotelnoho pidpryiemstva [Architecture as a factor in shaping the image of the hotel business]. Suchasni tekhnolohii, materialy $i$ konstruktsii v budivnytstvi, no. 2, pp.102-106.

Postova Valentina, Lukyanets Alla

Vinnytsia Trade and Economic Institute Kyiv National University of Trade and Economics

\section{PECULIARITIES OF FORMATION AND MAINTENANCE OF THE IMAGE OF HOTEL AND RESTAURANT BUSINESS ENTERPRISES}

Currently, one of the components of the success of the enterprise is a positive image, which contributes to the growth of competitiveness and efficiency. Image is an important tool for achieving the strategic goals set by the company. In this regard, the importance of developing specific measures to form a positive image and reduce the risk of losing the reputation of the enterprise. The article considers the specifics of providing accommodation services in hotel facilities. The factors influencing the formation of a favorable image of service enterprises are identified, which are divided into 4 groups. It is established that the consumer of services, as a rule, is interested in conformity of the price and quality of the provided services. It is determined that in the complex of management functions at the enterprises of the service sector one of the leading places is occupied by the management of the customer service process. The main feature of the image of the hotel and restaurant company is the dependence of the perception of this institution on the tourist destination in which it is located. It is determined that this approach is to assign to each hotel or restaurant the image of the whole resort and all those who are there these institutions as a whole, because tourists probably already have an idea of destination, which is based not only on the tourist attractiveness of the region. Other features of the image of a hotel or restaurant should include the visual component of the image, the level of innovation and quality of services provided, and finally, cooperation with other institutions and networks. It is established that the image of the hotel and restaurant should not lose its relevance and, eventually, will cease to be an image as such. If the hotel and restaurant does not want to lose its position in the market, its rating should be constantly maintained, and the style - to be updated, at least in the introduction of minor elements of novelty that allow the institution to always remain "fresh", original and unforgettable. Prospects for further research may be the development of an effective strategy for the formation of a positive image for the hotel and restaurant business.

Key words: hotel and restaurant business, sphere of services, image, service, services, Public Relations.

JEL classification: L83, Z33 